\title{
Analysing the Impact of Customer Service among Taxi Drivers in the New Juaben South Municipality.
}

\section{Richard Amoasi, Seth Tuffour Osei-Tutu, Margaret Amoasi}

Faculty of Business and Management Studies

Department of Marketing Koforidua Technical University

Faculty of Business and Management Studies Department of Marketing

Koforidua Technical University

Entrepreneurial University College

\begin{abstract}
Marketing was previously considered as synonymous with selling of tangible products therefore much emphasis was placed on physical products to the service industry. Many people did not find it necessary to practice marketing in the service industry, not knowing that this is the sector that needs marketing. Kotler (1999) defined a service as any act of performance that one party can offer to another, that is essentially tangible as does not result in the ownership of anything. This research work was about Taxi Driver's level of awareness of the role of quality customer service in the provision of transport service to passengers in New Juaben North. The research was to evaluate customers' perception about services provided by the Taxi drivers, to evaluate Taxi drivers understanding of quality customer service and to establish the relationship between taxi drivers and the customers. . The sample size for the study was one hundred and fifty (150). It comprised of one hundred (100) customers and fifty (50) taxi drivers. The researchers used non-probability sampling, convenience sampling and purposive sampling.

Researchers choose this topic simply because empirical evidence proves that Taxi drivers in New Juaben South do not value passengers, they feel they are doing the passengers a favour because of taxi's fastness as compared to the "Trotro". To help us carry out this research we developed two questionnaires for Taxi drivers and the passengers. The study revealed that Ghana Private Road Transport Union (GPRTU) and other Transport Associations organize training for its members to escape not from road accidents alone, but also how to handle passengers in that the passengers will intend develop positive relationships with them to improve customer relations and preferences towards taxi services than the Trotro which is in serious competition with the taxi business. Researchers concluded that providing quality service to passengers is the main marketing problem that Taxi drivers are facing and need special attention. The study recommends that various Transport Associations in conjunction with customer groups in New Juaben South Municipality must educate Taxi drivers on the importance of the customer and why it is necessary to satisfy the customers.
\end{abstract}

Keywords: taxi, trotro, customer relationship, quality service, customer value.

\section{Introduction}

Marketing was previously considered as synonymous with selling of tangible products therefore much emphasis was placed on physical products to the neglect of the service industry. Many people did not find it necessary to practice marketing in the service industry, not knowing that this is the very sector that needs marketing the most.

A service is said to fulfill a need and want and are those separate identifiable and intangible activities which provides need satisfaction and are necessarily tied to the sale of any product. Kotler (1999) defined a 
service as any act of performance that one party can offer to another, that is essentially tangible as does not result in the ownership of anything.

To transport is the movement of people, animals and good from one location to another. Modes of transport include air, rail, road, water, Cable, Pipeline and space. The field can be divided into infrastructure, vehicles and operations. Transport is important because it enables trade between people, which is essential for the development of civilizations.

Transport infrastructure consists of the fixed installations including roads, railways, airways, Canals and pipelines and terminals such as airports, railway Stations, bus stations, warehouses, trucking terminals, refueling depots (including fueling docks and fuel stations), and seaports. Terminals may be used both for interchange of passengers and cargo and for maintenance.

Vehicles travelling on these networks may include automobiles, bicycles, buses, trains, trucks, helicopters, watercraft, people, spacecraft, and aircraft. In the transport industry, operations and ownership of infrastructure can be either public or private, depending on the country and mode. Passengers transport may be public or private, where operators provide schedules services. Freight transport has become focused on containerization, although bulk transport is used for large volumes of durable items. Transport plays an important part in economic growth and globalization, but most types causes air pollution and use large amounts of land. While it is heavily supported by government, through the construction of roads, good planning of transport is essential to make traffic flow and restrain urban sprawl.

Furthermore, customer service to the consumer means the efforts made by manufacturer or service provider to ensure that the product is available at the time in question, in place and in the condition requested. Consumer service has attracted much attention in recent years. Ghana Private Road Transport Union (GPRTU) is one of the organizations in Ghana that is offering transportation services to the public. The services offered by Ghana Private Road Transport Union satisfy the requirements of road transportation and thus satisfy the needs of road transportation, making the movement of goods and people easier.

\section{Customer Service}

According to Jamier (2002), "Customer service is a series of activities designed to enhance the level of customer satisfaction-that is, the feeling that a products or service has met the customer expectation". Customer service can be the expressed in personal and interpersonal skills such as communication skills, listening skills, language, gestures and posture, telephone techniques. According to Turban et al (2002), it is a series of activities designed to enhance the level of customer satisfaction - that is the feeling that a person (i.e. sales and service representative), or by automated means called self-service. This leads to objective one: to established whether customers are satisfied with the services of Taxi drivers in New Juaben South Municipality.

\section{The Customer Perceived Service Quality}

Customer perceived service quality is the customers own perception of the services based on different factors contributing to the service, from the process to the final outcome. According to Gronroos (2001), "quality is what customers perceive". Customers buying service consider everything that contributes to the process and the final outcome in making their assessments of the service. However, the subjective assessment of the actual service experiences is the customer perceived service quality as pointed out by Looy et al (2003), Zeithaml et al (2006), and Gronroos (2001).

Sureschander et al (2002), points out that services firms have a difficulty envisioning and understanding what aspects of the service that define high quality to the consumers and at what levels, they are needed to be delivered. Also, that the aspect of managing a service interaction also requires understanding the complicated behaviour of employees that find its way into the customers perception of the service quality. On a careful inspection of the dimensions of quality, a major focus rests on the component of human interaction of the service delivery that consists of human beahviour and attitudes. This leads to objective two: whether the services rendered by the Taxi drivers are quality,

\section{Service Quality Management}


According to Palmer (2008), quality is determined by the difference between what a customer expects and perceived level of actual performance. These findings have evolved from a set of qualitative marketing research procedures, culminating in quantitative techniques for measuring service quality that is known as, SERQUAL (Parasuraman et al 1985).

Figure 1: SERVQUAL GAP MODEL

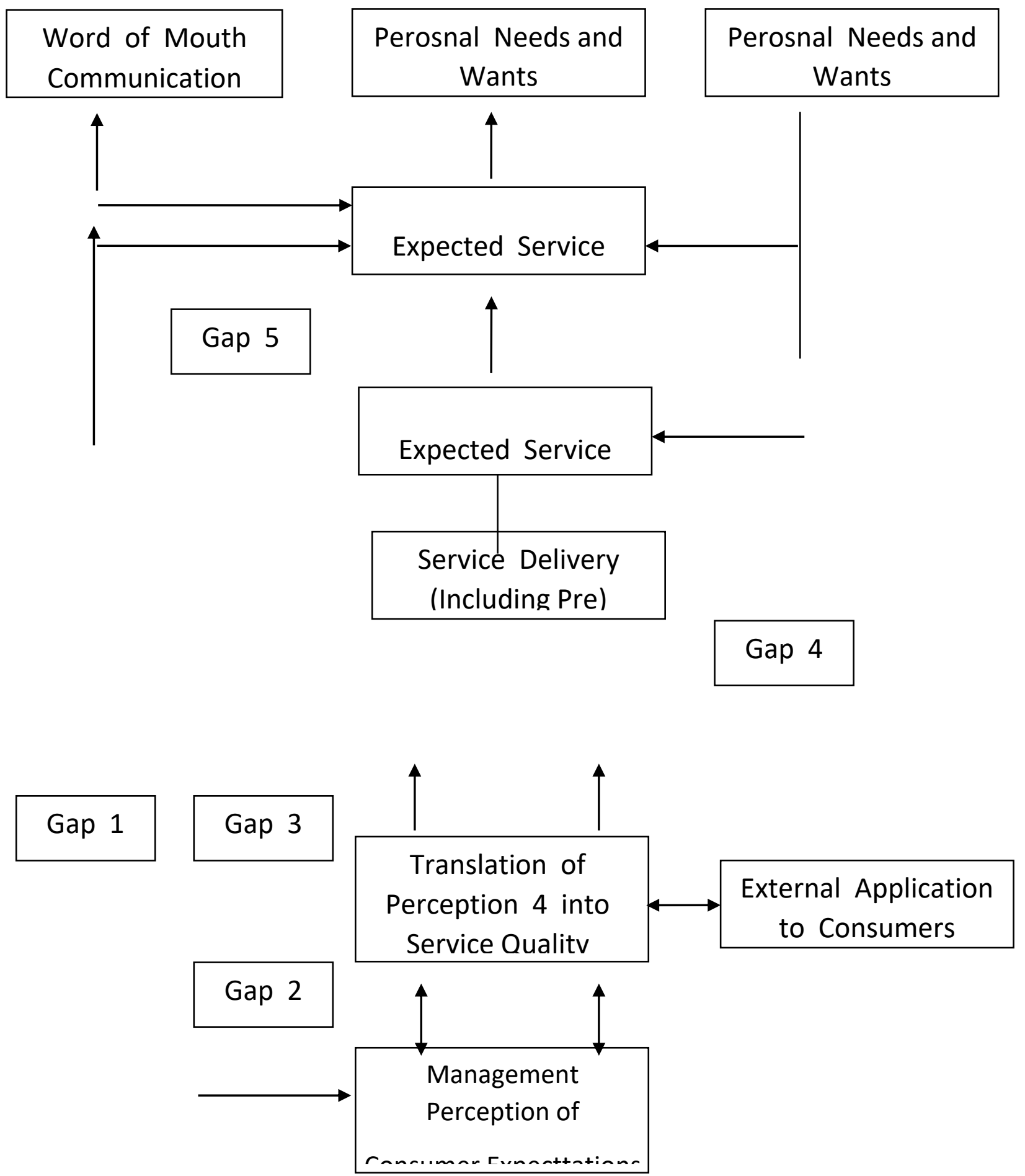

Source: A. Parasuraman, Valarie A. Zeithaml, and Leonard L. Berry, "A Conceptual model of Service Quality and its implication for Future Research", Journal of Marketing, 49 (1985): $41-50$

The SERVQUAL model has been widely applied in the service industry and can be used by companies to better understand the expectations and perceptions of their customers. It is applicable across a broad range of services industries and can be easily modified to take account of the specific requirements of a company. The model provides a framework or guideline for an investigatory instrument, which can be adapted or added to as required. SERVQUAL is originally based on a generic 14-item questionnaire, which is designed to cover five broad dimensions of service quality that the researchers consolidated from their original 
qualitative investigations. The five dimensions covered, with some description of each of them are as follows:

i. Reliability: Ability to perform the promised service dependably with consistency and accuracy. Reliability means performing the service right the first time.

ii. Responsiveness: The willingness to help customers and to provide prompt services.

iii. Assurance: The knowledge and courtesy of employees and their ability to convey trust and confidence.

iv. Empathy: The provision of caring and individual attention to customers' problems.

v. Tangibles: The appearance of physical facilities, such as good car tyres, the lorry parks. Good breaks, personal communication material etc.

Inability of any firm or service provider to meet these criteria reduces quality of customer service delivery. This leads to objective three: That is whether Taxi drivers manages the service quality and its implications on customer relationship.

\section{Customer Satisfaction}

Customers perceive service in terms of quality, but how satisfied they are with the overall experience, is what defines their satisfaction. Whether the customer is satisfied after purchase depends on the offer's performance or the customer service in this case, in relation to the customer expectations. However, according to Zeithaml et al (2006) although service quality and customer satisfaction are used interchangeably, there is indeed a distinction.

Customer's satisfaction is when the outcomes of the service matches the expectations of the service. As pointed out by Looy et al (2003), even though they differ one is a component of the other. Zeithaml et al (2003) defines it as the customer's evaluation of a product or service in terms of whether the product or service has met his meet ort expectations. Failure to meet needs results in dissatisfaction, or a poor perception of the service quality.

Satisfaction can be acknowledged in various senses depending on what needs the customer had before the service; it ranges from feelings of fulfillment, contentment, pleasure, delight, relief and ambivalence. Although it tends to be measured as a static quantity, it is dynamic and evolves over time being influenced by a variety of factors. Service quality is one of those factors that contribute to customers satisfaction, in other words a component of customer satisfaction measure. Objective four: to establish whether customers are satisfied with the

\section{Services rendered by the Taxi drivers. Methodology}

The case study was chosen to be Taxi drivers and the target population were customers of these drivers in the New Juaben South Municipality (Koforidua). The study considered a sample size of one hundred and fifty (150) with a special focus on Taxi drivers and the customers to respond to the questionnaires

Taxi drivers in the New Juaben South Municipality were chosen because of their accessibility to the researchers. To obtain a representative sample, a simple random sampling was used to draw the respondents. The researchers resorted to this technique because it is easy to understand and use.

Primary data collection method was used where data for the study was collected from the Taxi drivers and the customers of New Juaben South Municipality. This was done through administration of questionnaire, personal interviews and analyses of results. The instruments that were used to collect data were questionnaires, interviews and observations. An ample time of ten (10) days was given to both the drivers and the respondents to complete the questionnaire before they were collected. Personal interviews were done on the spot. To make the findings of this research simple, easy to read and understand, the analysis of both primary and secondary data collected were made in table form by the use of excel version 7 . 
Results and Discussions

Passengers Rating of Drivers Service Quality

Table 1: A table illustration passenger's ratings of driver's service quality.

\begin{tabular}{|l|c|c|}
\hline \multicolumn{1}{|c|}{ RESPONSE } & FREQUENCY & PERCENTAGE (\%) \\
\hline Very Poor & 0 & 0 \\
\hline Poor & 4 & 4.2 \\
\hline Good & 38 & 40 \\
\hline Very Good & 47 & 49.5 \\
\hline Excellent & 6 & 6.3 \\
\hline Total & $\mathbf{9 5}$ & $\mathbf{1 0 0}$ \\
\hline
\end{tabular}

\section{Source: Field Survey, August 2018}

The passengers have different perceptions of rating the service of the taxi drivers. Out of the sample size of one hundred (100), 4 respondents representing four point two percent $(4.2 \%)$ says the services are poor, thirty=eight respondents representing forty percent (40\%) says the services were good. Forty seven respondents representing forty nine point five percent (49.5\%) and six (6) of the respondents representing six point three percent says the service quality of drivers were excellent. It appeared that most of the respondents were satisfied of the quality of service rendered to them by the Taxi drivers. Those who were not satisfied complained about bad treatment meted to them during the periods of rainfall. They added that during these periods, the drivers only prefer dropping service.

Table 2: A Table illustrating customer dissatisfaction with Taxi drivers

\begin{tabular}{|l|c|c|}
\hline \multicolumn{1}{|c|}{ AREAS DISSATISFACTION } & FREQUENCY & PERCENTAGE (\%) \\
\hline Bad Conduct of Drivers & 20 & 21.05 \\
\hline Conditions of Taxis & 25 & 26.3 \\
\hline Over Speeding & 20 & 21.05 \\
\hline Hostile to Passengers & 5 & 5.3 \\
\hline Not able to put Goods on the Booth & 10 & 10.5 \\
\hline Driver's dressing & 15 & 15.8 \\
\hline Total & $\mathbf{9 5}$ & $\mathbf{1 0 0}$ \\
\hline
\end{tabular}


Source: field survey, August 2018

Passengers go for services that will satisfy them, as they buy the services, they expect value for their money. When passengers were given questionnaires to fill on areas of dissatisfaction, some of the passengers complaints about bad conduct of drivers. This set of passengers representing ten (10) respondents said some taxi driver's insults passengers sometimes when they ask for their rights. According to twenty-five (25) of the respondents, the least they talked about was discomfort in vehicles. These respondents talked on areas like conditions of taxis. Many also stressed on the use of the Daewoo Matrix for taxi services. They emphasised on the fact that the three passengers at the back seat creates discomfort because the space at the back seat isn't enough for three people. They argued the most of the seats in the taxis were torn which stains their dresses each time they bored the taxis.

Ten (10) complained bitterly with over speeding by these drivers. Respondents after shopping needed their luggage to be put in the boot for them, but some drivers refuses to do that. Ten (10) of them said drivers felt lazy to put luggage's in the booth whiles five (5) said the drivers were not friendly at all.

\section{Drivers Response Whether Customer Service Training is Organized for Them}

Table 3: A table showing whether the drivers are trained on customer service levels.

\begin{tabular}{|l|c|c|}
\hline \multicolumn{1}{|c|}{ RESPONSES } & FREQUENCY & PERCENTAGE (\%) \\
\hline Yes & 40 & 87 \\
\hline No & 6 & 13 \\
\hline Total & $\mathbf{4 6}$ & $\mathbf{1 0 0}$ \\
\hline
\end{tabular}

\section{Source: Field Survey, August 2018}

From the table, it is clear that almost all the taxi drivers agreed to the fact that customer service training is always organised for them from time to time at the station by the station masters and that due to the nature of their work, they are unable to have their customer training sessions at any hotel or a place outside the station. They agreed that the training given them gives them the insight into what customer service is and how to offer quality service to the passengers. It was discovered that a few of the drivers who disagreed to the fact that customer service training is given to them were not stationed drivers by ply their trade along the road side and thus are roaming drivers.

Table 4: A table showing the responses to the effectiveness of customer service training.

\begin{tabular}{|l|c|c|}
\hline \multicolumn{1}{|c|}{ RESPONSES } & FREQUENCY & PERCENTAGE (\%) \\
\hline Yes & 41 & 89 \\
\hline No & 5 & 11 \\
\hline Total & $\mathbf{4 6}$ & $\mathbf{1 0 0}$ \\
\hline
\end{tabular}

\section{Source: Field Survey, August 2018 .}

When respondents again were asked whether the training had improved their behaviour towards passengers, about eighty nine percent $(89 \%)$ of them agreed to the fact that their behaviours have been improved 
towards the customers and eleven percent $(11 \%)$ of them said "No" with no reasons. Reasons given in support of the training by the majority of the drivers were that some said it has really made them to be always patient with troublesome passengers who are already troubled before boarding the taxi whiles others said it enable them to always obey road signs.

\section{Respondent's on How They Treated Customer Complaints}

When respondents who were the drivers asked of how customer's complaints were been treated, the following were the responses they gave:

Most of them said that they patiently calm down the passengers who were troubled and if possible solve the problem immediately by giving life experiences and other practical examples live has taught them. Some said they apologized for any misconduct and pleaded when they know they have offended the customer. Others said, when the problem goes beyond them, they transfer it to their supervisors popularly known as the bookmen. When the porters were also asked how they handle customer complaints, these were the response given. They handled the problem tactically. They made it known that they don't have a committee set to handle the problem of customer complaints and that they try to come out with solutions based on their life experiences and when the issue is beyond them, they also report to the station masters.

\section{Responses to Whether Taxi Drivers Keep Records on Customer Complaints}

Table 5: Shows whether taxi drivers keep records of customer's complaints.

\begin{tabular}{|l|c|c|}
\hline \multicolumn{1}{|c|}{ RESPONSES } & FREQUENCY & PERCENTAGE (\%) \\
\hline Yes & 10 & 22 \\
\hline No & 36 & 78 \\
\hline Total & $\mathbf{4 6}$ & $\mathbf{1 0 0}$ \\
\hline
\end{tabular}

Source: Field Survey, August 2018.

Though respondents attempted to solve or address complaints, from the table above, only twenty two percent $(22 \%)$ of respondents said "Yes" they keep the records on customer complaints. These percentage of respondents represented Higher National Diploma and First Degree holders who because of lack of employment in their respective fields have taken into driving to be able to get their daily bread. Majority of them representing seventy eight percent $(78 \%)$ said "No". This high percentage of drivers who kept no records on customer complaints were those perceived to have low education with some leaving school as early as the primary school. This is so because there is a high percentage of perception that commercial drivers such as taxi drivers are illiterate.

\section{Conclusion and Recommendations}

The study was designed to assess the role that taxi drivers play in the provision of quality transport services to passengers. The study was undertaken to examine the level of taxi driver's awareness of quality services in the transport industry. The concept of customer's satisfaction which is the main element of the marketing concept presupposes that passenger's needs must be adequately satisfied by service operators (taxi drivers) but this has been given little attention.

It was found out that GPRTU and other Transport Associations organized training for its members to increase customer satisfaction and to curb road accidents to ensure the customers' safety but this is not done frequently.

It was ascertained that customers patronize the services of taxi drivers not because of the level of quality services but rather they have no option since it is quite faster travelling with the Taxi than the "Trotro". Customers have the perception that taxi drivers are not there to help them but rather to make money out of them which is why they charge expensive lorry and luggage fares especially after rainfalls.

The research also revealed that the requirement of quality services has been met, yet passengers have to be contended with what is at their disposal because they have no better alternative from which they will choose. 
Taxi drivers have got an idea about customer services but do not know about the quality service and its implementation which is part of concept of customer's satisfaction.

The GPRTU, Private Transport Companies and Associations and the Ministry of Roads and Transport when given training on quality service should ensure that the time ffor the training is appropriate preferably in the night when they have closed from work or organize the training in sessions to enable almost all the taxi drivers participate in the training.

- External (macro) environmental factors such as government policies as the education requirement for commercial drivers such as taxi drivers, and economic conditions also have effect on the quality services delivery of the taxi drivers or operators.

Providing quality services is the main marketing problem which taxi drivers are facing and need special attention from the appropriate authorities for assistance and enforcement.

GPRTU and other Transport Associations in conjunction with the Ministry of Roads and Transport should organize courses for taxi operators frequently for them to curb road accidents, be friendly with road signs so as to ensure customer safety and improving on customer satisfaction.

GPRTU and other Transport Associations in conjunction with the Customer Association of Ghana must educate taxi drivers on the importance of a customer and why it is necessary for them to value customers.

Taxi operators must not only be business oriented but also put the passenger first and listen to their suggestions. They should ensure continuous maintenance, repairs and spraying of their vehicles to keep them in shape.

Transport Companies and Taxi owners should try as much as possible to employ drivers who can read and write so they can keep records on passengers' complaints so they will be able to address similar problems effectively and to devise good strategies in handling new problems when they occur.

Drivers should learn to dress well and keep their taxis clean to be able to attract the middle and high class customers who may need their services over long distance and dropping.

Most drivers do not want to accept their mistakes, so they should always learn to accept their mistakes work together with the customer in ensuring that what happened doesn't repeat itself or the issue is analysed and handled appropriately the next time.

\section{References}

[1] Anderson, E. w. (1996), “Customers Satisfaction and Price Tolerance”, Marketing Letter 7(3), 19-30

[2] Anderson, E. W. and Sullivan, M. (1993), "The Antecedents and consequences of customer satisfaction for firms" Marketing Science, Vol. 12, Spring, Pg. 125- 143.

[3] Anderson, E. W., Fornell, C. and Lehmann, D. R. (1994), "Customer Satisfaction, Market Share and Profitability: Findings from Sweden”, Journal of Marketing, 58 (3), 53-66.

[4] Bansal, S. Gupta, G. (2001), Building Customer Loyalty Business-to- Business Commerce. In J. N. Sheth, A. Parvatiyar \& G. Shainesh, (2001) eds., Customer Relationship Management. New Delhi, Tata, McGraw-Hill, Pg. 3-25.

[5] Berry, L. L. and Parasuraman, A. (1991), Marketing Services: Competing through Quakityt, New York Press, Pg. 16.

[6] Bitner, M. (1990) Evaluation of service encounters: the effects of psychical surroundings and employee's responses' Journal of Market, 54 (2), 69-82.

[7] Kotler, P. (2000), Marketing Management, the Millennium edition, Prentice Hall, U. S. A.

[8] Lacobucci, D., Ostrom, A. and Grayson, K. (1995) "Distinguishing Service quality and customer satisfaction: the voice of the customer", Journal of Consumer Psychology 4(3), 277-303.

[9] Matzler, K. Hinterhuber, H. H., Bailom, F., Sauerwein, E. (1996), "How to Delight Your Customers" Journal of Product and Brand Management, Vol. 5, No. 2, Pg. 6-18

[10] Oliver, R. L. (1980), "A Cognitive Model of the Antecedents and Consequences of Satisfaction Decisions, "Journal of Marketing Research", Vol. 17, No. 4, Pg. 460-469.

[11] McDaniel, C. Lamb Jr. C. W. and Hair Jr., J. F. (2006) Introduction to Marketing 8th Edition, Ohio, Thomson Higher Education, USA.

[12] Parasuraman, A., Zeithmal V. A. and Berry, L. L. (1988) "SERVQUAL: A multiple-item scale for 
measuring consumer perceptions of service quality", Journal of Retailing, 64 (1) 12-40.

[13] Swan, J. E. and Coombs, L. J. (1976) "Product Performance and Consumer Satisfaction:a concept", Journal of Marketing, 40 (2), 25-33.

[14] Parasuraman, A. Zeithmal. V. A. and Berry, L. L. (1985), "A Conceptual model of service quality and it implications for future research", Journal of Marketing 49 (4), 41-50.

[15] Swan, J. E. and Coombs, L. J. (1976), "Product Performance and Consumer Satisfaction: a new concept", Journal of Marketing, 40 (2). 25-33.

[16] Etzel et al, (2001) Marketing 12 Edition, McGraw-Hill Companies. United Kingdom.

[17] Futrell (2005) ABC'S of the relationship selling through service, 8th Edition, New York: McGrawHill Companies, Inc.

[18] Gabott M and Hogg G (1997) Contemporary Service Management, The Dryden Press, Britain

[19] jobber Principles and Practice of Marketing, 5th Edition, McGraw-Hill International Limited, United Kingdom.

[20] Kurtz D. L. and Boone L. E. Principles of Marketing, 3rd Edition, Thomson SouthWestern Corporation, Canada.

[21] Kotler (1999) Marketing Management, 12th Edition, Prentice-Hall International Limited.New Jersey, USA.

[22] Martin C. (1992) the Customer Service Planner, 3rd Edition, Butterworth. New Delhi, India.

[23] Longman Dictionary of Contemporary English, 3rd Edition.

[24] Metters R. et al (22003) Service Operations Management, Thomson South Western Cooperation. Canada.

[25] Nigel Hill (1994) BTEC Professional and Degree Courses Marketing, 2nd Edition Great Britain.

[26] Palmer Principles of Services Marketing, 4th Edition, New York: Oxford University Press.

[27] Smith P. R. and Taylor Marketing Communication, 3rd Edition, Kogan Press, United Kingdom. 